M.I. Baikenov, A.Zh. Satybaldin, Z.K. Aitpayeva, A.B. Karimova, N.Zh. Rakhimzhanova

Ye.A.Buketov Karaganda State University, Kazakhstan (E-mail: raximzhanova82@mail.ru)

\title{
Investigation of the influence of electrohydroimpulse technology on physico-chemical characteristics of oil sludges
}

\begin{abstract}
The article is devoted to the investigation of the influence of electrohydropulse processing of Zhana-Ozen oil sludge using the method of probabilistic-deterministic planning of the experiment, in which the mutual influence of various factors is taken into account. It has been established that the dominant factors that influence the decrease in the kinematic viscosity, the increase in the yield of light and middle fractions up to $300^{\circ} \mathrm{C}$ from the Zhana-Ozen oil sludge in the process of destruction of the heavy part of the organic mass of oil are inter-electrode distance, processing time and discharge voltage.
\end{abstract}

Keywords: electrohydropulse technology, oil sludge, kinematic viscosity, interelectrode distance, voltage.

Modern methods of processing, utilization of oil sludge and oil-bearing technogenic raw materials are not technologically and energy-intensive and require significant capital investments, so the volumes of utilization are lagging behind the volumes of their formation and new ones are added to the accumulated volumes. The level of soil contamination with oil products and oil sludge has now approached 10 million cubic meters. In addition, the land area contaminated or damaged as a result of various accidents at gas and oil pipelines, plants and other facilities is constantly growing [1].

The choice of the method for processing and neutralizing oil sludge depends mainly on the amount of petroleum products contained in them and in each specific case a differentiated approach, taking into account both environmental and economic indicators, is required.

There are various ways of processing oil-containing technogenic raw materials:

- thermal-combustion in open barns, furnaces of various types, production of bituminous residues;

- biological-microbiological degradation in soil directly in storage areas, biothermal decomposition;

- physical - burial in special repositories, separation in the centrifugal field, vacuum filtration and filtration under pressure;

- physico-chemical - the use of specially selected reagents that change physico-chemical properties, followed by treatment on special equipment;

- chemical - extraction with the help of solvents, solidification with the use of mineral (cement, liquid glass, clay) and organic (epoxy and polystyrene resins, polyurethanes, etc.) additives [2].

Data on the accumulation of oil sludge in Kazakhstan show that their processing does not cover the volume of annual formation. Thus, it is necessary not only to find processing technologies, but also to recommend and adapt special technology from many existing ones to each specific type of waste. The choice is further complicated by the fact that many technologies can be applied to individual types of waste, but none of them meets the universality requirement and cannot be applied to all types of wastes.

In this regard, the use of the phenomenon of electrohydropulse treatment in the processing of oil sludges is of great practical interest [3].

One of the types of complex extreme impact is the effect of electrohydraulic discharge, which combines the simultaneous impact on the substance of strong mechanical compression, powerful ultrasound, hard xray, ultraviolet and infrared radiation. The electromagnetic fields produced during the discharge also exert a strong influence both on the discharge itself and on the ionic processes occurring in the surrounding liquid. Under their influence, various physical changes and chemical reactions occur in the material being processed. It has been established that the following factors such as discharge voltage, processing time, capacitor bank capacity, interelectrode distance of the processing cell, and effect of the hydrogen donor influence the change in the kinematic viscosity and the yield of the light and middle fractions from the oil sludge.

We investigated the effect of the duration of the electrohydropulse treatment, the interelectrode distance in the stand unit cell, the capacitance of the capacitor bank and the impulse voltage in the bench set-up to 
reduce the kinematic viscosity of the oil and increase the yield of light and middle fractions from the oil sludge. The object of investigation is the oil sludge of Zhana-Ozen of the Mangystau region.

We carried out laboratory studies using the method of probabilistic-deterministic planning of the experiment, in which the mutual influence of various factors is taken into account, to determine the optimal conditions and create a mathematical model of the Zhana-Ozen oil sludge treatment process with the help ofelectrohydropulse action [4].

The program of probabilistic-deterministic planning of the experiment was created by the order of Doctor of Technical Sciences, Professor S.V. Belyaev (ChMI named after Abishev of MES RK). The author of the program is Ph.D., Associate Professor V.N. Fomin The ExprDraw and ExprMake modules developed by Anton Grigoriev [4-7] are used to display mathematical formulas.

The investigated factors and their levels are presented in Table 1.

$\mathrm{Tab}$ a 1

Factors studied and their levels

\begin{tabular}{|l|c|c|c|c|c|}
\hline \multicolumn{1}{|c|}{ Factors } & 1 & 2 & 3 & 4 & 5 \\
\hline$X_{1}$ - processing time, min & 1 & 2 & 3 & 4 & 1 \\
\hline$X_{2}-$ capacitor bank capacity, $\mathrm{uF}$ & 0.1 & 0.25 & 0.5 & 0.75 & 0.1 \\
\hline$X_{3}$ - interelectrode distance, $\mathrm{mm}$ & 6 & 7 & 8 & 9 & 6 \\
\hline$X_{4}-$ volume of catalyst added, $\mathrm{g}$ & 2.17 & 4.34 & 6.51 & 8.68 & 2.17 \\
\hline$X_{5}-$ volume of added donor (alcohol), $\mathrm{ml}$ & 10 & 20 & 30 & 40 & 10 \\
\hline
\end{tabular}

Since the dependence of the yield of liquid products from high-viscosity oil on the above factors is nonlinear, the method of mathematical design of an experiment based on nonlinear multiple correlation was used. Variable factors were varied at 5 levels. The experimental design matrix is shown in Table 2. Each row of the matrix corresponds to the experimental conditions, and the structure of the matrix is such that, in all experiments, the level of any factor occurs once with each level of all factors.

Ta a le 2

Experimental design matrix

\begin{tabular}{|c|c|c|c|c|c|c|c|c|c|c|}
\hline & \#exp. & $\begin{array}{c}X_{1}, \\
\mathrm{~min}\end{array}$ & $\begin{array}{c}X_{2}, \\
\mathrm{uF}\end{array}$ & $\begin{array}{c}X_{3}, \\
\mathrm{~mm}\end{array}$ & $\begin{array}{c}X_{4}, \\
\mathrm{~g}\end{array}$ & $\begin{array}{c}X_{5}, \\
\mathrm{ml}\end{array}$ & $\begin{array}{c}Y_{1 \text { exp. }}, \\
\mathrm{mm}^{2} / \mathrm{s}\end{array}$ & $\begin{array}{c}Y_{1 \text { theor. }}, \\
\mathrm{mm}^{2} \mathrm{~s}\end{array}$ & $\begin{array}{c}Y_{2 \text { exp. }}, \\
\%\end{array}$ & $\begin{array}{c}Y_{\text {2theor. }}, \\
\%\end{array}$ \\
\hline I & 1 & 1 & 0.1 & 6 & 2.17 & 10 & 6.49 & 6.4753 & 16.75 & 19.3513 \\
\hline & 2 & 1 & 0.25 & 7 & 4.34 & 20 & 6.53 & 6.3652 & 35.43 & 27.5111 \\
\hline & 3 & 1 & 0.5 & 8 & 6.51 & 30 & 5.71 & 5.8326 & 34.07 & 28.1789 \\
\hline & 4 & 1 & 0.75 & 9 & 8.68 & 40 & 5.32 & 5.2757 & 23.51 & 25.8662 \\
\hline II & 5 & 2 & 0.1 & 7 & 6.51 & 40 & 5.36 & 5.6627 & 18.35 & 21.9999 \\
\hline & 6 & 2 & 0.25 & 6 & 8.68 & 30 & 5.96 & 6.0648 & 44.92 & 27.0224 \\
\hline & 7 & 2 & 0.5 & 9 & 2.17 & 20 & 5.72 & 5.553 & 20.79 & 22.2943 \\
\hline & 8 & 2 & 0.75 & 8 & 4.34 & 10 & 5.12 & 4.8923 & 24.08 & 21.8885 \\
\hline III & 9 & 3 & 0.1 & 8 & 8.68 & 20 & 6.22 & 5.9686 & 28.21 & 29.6722 \\
\hline & 10 & 3 & 0.25 & 9 & 6.51 & 10 & 4.67 & 5.2587 & 40.54 & 23.9503 \\
\hline & 11 & 3 & 0.5 & 6 & 4.34 & 40 & 5.91 & 5.3391 & 19.78 & 26.6007 \\
\hline & 12 & 3 & 0.75 & 7 & 2.17 & 30 & 5.01 & 5.2556 & 19.98 & 27.2807 \\
\hline IV & 13 & 4 & 0.1 & 9 & 4.34 & 30 & 6.23 & 5.9072 & 22.9 & 33.4732 \\
\hline & 14 & 4 & 0.25 & 8 & 2.17 & 40 & 5.08 & 5.2635 & 52.35 & 28.1584 \\
\hline & 15 & 4 & 0.5 & 7 & 8.68 & 10 & 5.4 & 5.1711 & 25.36 & 33.5923 \\
\hline & 16 & 4 & 0.75 & 6 & 6.51 & 20 & 5.36 & 5.7338 & 47.99 & 39.8488 \\
\hline
\end{tabular}

The $Y_{1 \text { exp. }}$ and $Y_{2 \text { exp. }}$ columns show the results of all the experiments to determine the kinematic viscosity of the Zhana-Ozen oil sludge, which was pretreated with an electrohydropulse effect (EHE). $Y_{1 \text { exp. }}$ is the yield of the fraction up to $300^{\circ} \mathrm{C}$ from the oil sludge, $Y_{2}$ exp. is the calculated kinematic viscosity of the fraction up to $300^{\circ} \mathrm{C}$, and $Y_{1}$ theor. and $Y_{2}$ theor. are calculated values of the yield of light and middle fractions up to $300{ }^{\circ} \mathrm{C}$ on the basis of the generalized equation of Protod'yakonov-Malyshev. The matrix for planning the experiment for the preliminary treatment of oil sludge by means of electrohydropulse action is given in Table 2. 
If the interval of the change of functions does not go beyond the permissible spread or confidence interval, then the functions are significant. Therefore, each function was checked for significance using the nonlinear multiple correlation coefficient (1) $R$ and the significance $t_{\mathrm{R}}(2)$ of this coefficient:

$$
\begin{aligned}
& R=\sqrt{1-\frac{(N-1) \sum_{1}^{N}\left(Y_{\text {exp. }}-Y_{\text {theor. }}\right)^{2}}{(N-K-1) \sum_{1}^{N}\left(Y_{\text {exp. }}-Y_{\text {mean }}\right)}}>0.66 ; \\
& t_{R}=\frac{R \sqrt{n-k-1}}{1-R^{2}}>2,
\end{aligned}
$$

where $R$ - is the coefficient of multiple correlation; $N$ - is the number of points described; $K$ - is the number of active factors; $Y_{\text {exp. }}-$ is the experimental result; $Y_{\text {theor. }}-$ is the theoretical result; $Y_{\text {mean }}-$ is the mean experimental value (see Fig.).

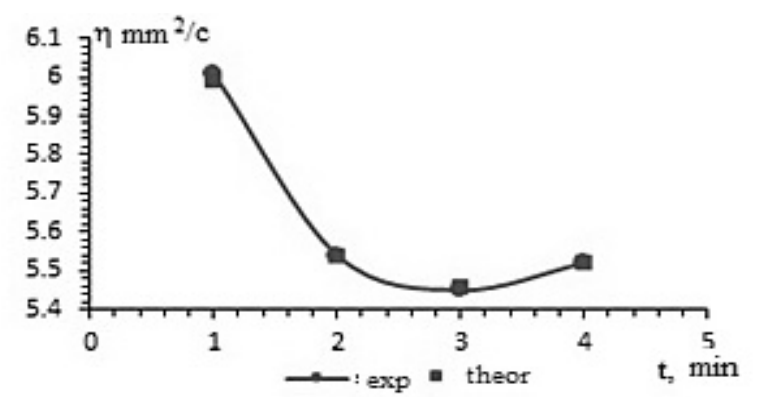

a)

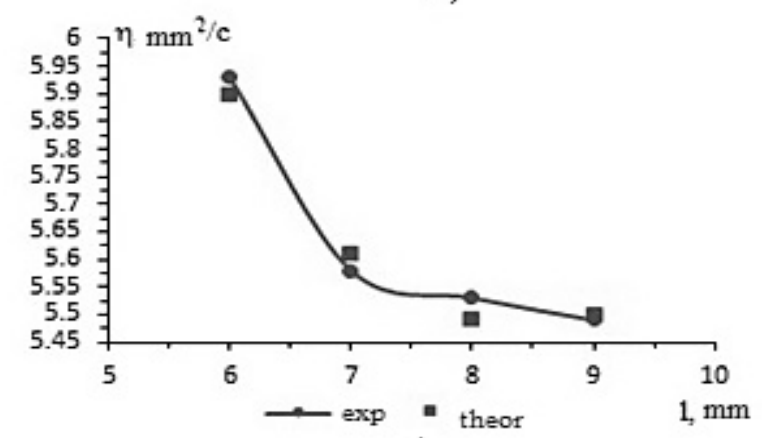

c)

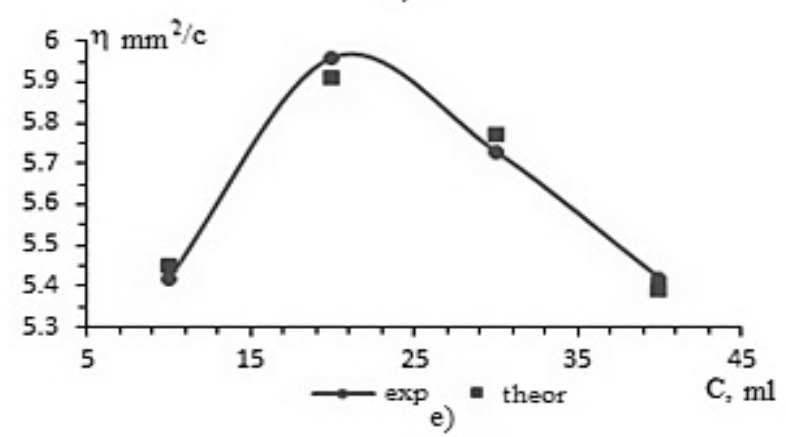

$X_{1}$ - on processing time; $X_{2}$ - on condenser battery capacity; $X_{3}$ — on interelectrode distance;

$X_{4}$ - on consumption of added catalyst; $X_{5}$ - from the flow rate of the added hydrogen donor (alcohol)

Figure. Particular dependences of decrease in kinematic viscosity of light and middle fractions up to $300{ }^{\circ} \mathrm{C}$

The least squares method was used for the mathematical description of the graphical dependence on various factors. The values of the partial functions and the calculated values of the partial functions of the change in the kinematic viscosity and the yield of the fraction up to $300{ }^{\circ} \mathrm{C}$ respectively for each factor are given in Tables 3-6. 
Theoretical and experimental values of particular functions for kinematic viscosity

\begin{tabular}{|c|c|c|c|c|c|c|}
\hline \multirow{2}{*}{ Function } & & \multicolumn{4}{|c|}{ Levels } & \multirow{2}{*}{ Mean } \\
\cline { 3 - 7 } & & 1 & 2 & 3 & 4 & \\
\hline \multirow{2}{*}{$Y_{1}=5.562 e^{0.07791 X_{1}} X_{1}^{-0.2306}$} & theor. & 5.99 & 5.54 & 5.46 & 5.52 & 5.62 \\
\hline \multirow{2}{*}{$Y_{2}=5.519 e^{-0.07282 X_{2}} X_{2}^{-0.04089}$} & exp. & 6.01 & 5.54 & 5.45 & 5.52 & 5.63 \\
\hline \multirow{2}{*}{$Y_{3}=29.69 e^{0.1777 X_{3}} X_{3}^{-1.495}$} & theor. & 6.00 & 5.74 & 5.47 & 5.29 & 5.62 \\
\hline & exp. & 6.08 & 5.56 & 5.69 & 5.20 & 5.63 \\
\hline \multirow{2}{*}{$Y_{4}=5.619+\frac{0.05041}{X_{4}}$} & theor. & 5.90 & 5.61 & 5.49 & 5.5 & 5.63 \\
\cline { 2 - 8 } & exp. & 5.93 & 5.58 & 5.53 & 5.49 & 5.63 \\
\hline \multirow{2}{*}{$Y_{5}=2.695 e^{-0.01783 X_{5}} X_{5}^{0.3816}$} & theor. & 5.64 & 5.63 & 5.62 & 5.62 & 5.63 \\
\cline { 2 - 8 } & exp. & 5.58 & 5.95 & 5.28 & 5.73 & 5.63 \\
\hline
\end{tabular}

Theoretical and experimental values of the partial functions of fractions yield up to $300{ }^{\circ} \mathrm{C}$

\begin{tabular}{|c|c|c|c|c|c|c|}
\hline \multirow{2}{*}{ Function } & & \multicolumn{4}{|c|}{ Levels } & \multirow{2}{*}{ Mean } \\
\hline & & 1 & 2 & 3 & 4 & \\
\hline \multirow{2}{*}{$Y_{1}=18.2 e^{0.4228 X_{1}} X_{1}^{-0.7264}$} & theor. & 25.23 & 23.30 & 26.88 & 33.77 & 27.29 \\
\hline & exp. & 27.44 & 27.04 & 27.13 & 37.15 & 29.69 \\
\hline \multirow{2}{*}{$Y_{2}=\frac{1}{0.0381-0.005184 X_{2}}$} & theor. & 26.12 & 26.66 & 27.67 & 28.72 & 27.29 \\
\hline & exp. & 21.55 & 43.31 & 25 & 28.89 & 29.69 \\
\hline \multirow{2}{*}{$Y_{3}=\frac{1}{0.02893+0.000717 X_{3}}$} & theor. & 28.21 & 27.6 & 26.97 & 26.4 & 27.29 \\
\hline & exp. & 32.36 & 24.78 & 34.68 & 26.94 & 29.69 \\
\hline \multirow{2}{*}{$Y_{4}=33.13-\frac{14.35}{X_{4}}$} & theor. & 24.27 & 27.37 & 28.49 & 29.04 & 27.29 \\
\hline & exp. & 27.47 & 25.55 & 35.24 & 30.5 & 29.69 \\
\hline \multirow{2}{*}{$Y_{5}=6.814 e^{-0.03246 X_{5}} X_{5}^{0.7362}$} & theor. & 24.7 & 29.83 & 28.99 & 28.66 & 27.29 \\
\hline & exp. & 26.68 & 33.11 & 30.47 & 28.5 & 29.69 \\
\hline
\end{tabular}

Coefficient of correlation $R$ for particular functions and its significance $t_{R}$

\begin{tabular}{|c|c|c|c|}
\hline Function & $R$ & $t_{R}$ & Significance of the function \\
\hline$Y_{1}$ & 1.00 & $1.10<2$ & Significant \\
\hline$Y_{2}$ & 0.82 & $3.52>2$ & Significant \\
\hline$Y_{3}$ & 0.98 & $32.23>2$ & Significant \\
\hline$Y_{4}$ & 0.58 & $1.22<2$ & Significant \\
\hline$Y_{5}$ & 0.98 & $39.6>2$ & Not significant \\
\hline
\end{tabular}

\section{Coefficient of correlation $\boldsymbol{R}$ for particular functions at light fractions output} up to $300{ }^{\circ} \mathrm{C}$ and its significance $t_{R}$

\begin{tabular}{|c|c|c|c|}
\hline Function & $R$ & $t_{R}$ & Significance of the function \\
\hline$Y_{1}$ & 0.92 & $8.89>2$ & Significant \\
\hline$Y_{2}$ & 0.62 & $1.42<2$ & Significant \\
\hline$Y_{3}$ & 0.57 & $1.19<2$ & Not significant \\
\hline$Y_{4}$ & 0.28 & $0.43<2$ & Not significant \\
\hline$Y_{5}$ & 0.94 & $11.06>2$ & Significant \\
\hline
\end{tabular}


As a function of the response of the influence of the electrohydropulse action, we adopted the decrease in the kinematic viscosity of the hydrogenate and the yield of the fraction up to $300{ }^{\circ} \mathrm{C}$. The mathematical model of the process of treatment of heavy oil by means of electrohydropulse action is based on the Protod'yakonov-Malyshev formula.

The experiment performed under these conditions gives a good agreement with the theoretically calculated value of the decrease in the kinematic viscosity of hydrogenate and the yield of the fraction up to $300{ }^{\circ} \mathrm{C}$ from the treated oil hydrogenate.

Thus, we found that the dominant factors affecting the decrease in the kinematic viscosity, the increase in the yield of light and middle fractions up to $300{ }^{\circ} \mathrm{C}$ from the Zhana-Ozen oil sludge in the process of destruction of the heavy part of the organic mass of oil are: interelectrode distance, processing time and discharge voltage. The optimal conditions for carrying out the process of destruction of the Zhana-Ozen oil sludge by means of electrohydropulse treatment are: $X_{1}$ - treatment time 4-8 minutes; $X_{2}$ - capacitor bank capacitance, $C-0.1 \mu \mathrm{F} ; X_{3}-$ interelectrode distance, $L-4-8 \mathrm{~mm} ; X_{4}-$ quantity of added donor (catalyst $-6.51 \mathrm{~g} ; X_{5}$ - the amount of added alcohol $-10-30 \mathrm{ml}$ per kg of raw material.

The results obtained on the study of the group and individual composition of hydrogenates from the Zhana-Ozen oil sludge allow us to state that electrohydropulse treatment not only increases the destruction reaction rate of the heavy portion of the Zhana-Ozen oil sludge in the presence of catalytic additives, but also catalyzes the hydrogenation and hydrogenolysis reactions in parallel.

\title{
References
}

1 Бочаров В.С. Нефтебитуминозные породы / В.С. Бочаров, Н.К. Надиров, И.П. Кривцов и др. // Техника и технология добычи и транспортирования. - Алма-Ата, 1987. — 200 с.

2 Мазлова Е.А. Шламовые отходы нефтегазовых компаний / Е.А. Мазлова, И.А. Меньшикова // Защита окружающей среды в нефтегазовом комплексе. - 2010. - № 1. - С. 21-22.

3 Крупец В.И. Электрогидроимпульсная дезинтеграция материалов / В.И. Крупец, А.Ф. Усов, В.А. Цукерман. - М.: Наука, 2002. - 324 с.

4 Самарина О.А. Совершенствование технологии обработки высококонцентрированных сточных вод накопителей нефтехимических предприятий: автореф. дис. ... канд. техн. наук: 05.23.04 / О.А. Самарина. — Пенза, 2011. — 20 с.

5 Цзин Голинь. Перспективы развития процессов переработки нефтешламов / Цзин Голинь, Луань Минмин, Чень Тинтин // Химия и технология топлив и масел. - 2011. — № 4. - С. 44-54.

6 Фердман В.М. Комплексная технология утилизации нефтешламов и ликвидация нефтешламовых амбаров в промысловых условиях: автореф. дис. ... канд. техн. наук: 03.00.16 / В.М .Фердман. — Уфа, 2002. — 24 с.

7 Надиров Н.К. Высоковязкие нефти и природные битумы. Добыча. Подготовка. Транспортировка. - Алматы: Ғылым, 2001. - T. 2. - 344 с.

М.И. Байкенов, А.Ж. Сатыбалдин, З.К. Айтпаева, А.Б. Каримова, Н.Ж. Рахимжанова

\section{Мұнай шайырының физика-химиялық қасиеттеріне электргидроимпульсті технологияның әсерін зерттеу}

\begin{abstract}
Мақала түрлі факторлардың ықпалы ескерелетін тәжірибені ықтималды-детерминді жоспарлау әдісін қолдану арқылы Жаңа Өзен мұнай шайырының физика-химиялық сипаттамасына электргидроимпульсті өңдеудің әсерін зерттеуге арналған. Мұнайдың ауыр органикалық массасының деструкциясы үрдісі барысында Жаңа Өзен мұнай шайырының $300^{\circ} \mathrm{C}$ температураға дейінгі жеңіл және орта фракциялардың шығымын арттыратын және кинетикалық тұтқырлықты төмендетуге әсер ететін негізгі факторлар анықталды, олар: электродаралық қашықтық, өңдеу ұзақтығы және разрядты кернеу.
\end{abstract}

Кілm сөздер: электргидроимпульсті технология, мұнай шайыры, кинематикалық тұтқырлық, электродаралық қашықтық, кернеу. 


\title{
М.И. Байкенов, А.Ж. Сатыбалдин, З.К. Айтпаева, А.Б. Каримова, Н.Ж. Рахимжанова \\ Исследование влияния электрогидроимпульсной технологии на физико-химические характеристики нефтяных шламов
}

\begin{abstract}
Статья посвящена исследованию влияния электрогидроимпульсной обработки на физико-химические характеристики нефтяного шлама Жана Озен с использованием метода вероятностно-детерминированного планирования эксперимента, в котором учитывается взаимное влияние различных факторов. Установлено, что доминирующими факторами, влияющими на уменьшение величины кинематической вязкости и увеличение выхода легкой и средней фракций до $300{ }^{\circ} \mathrm{C}$ из нефтешлама Жана Озен в процессе деструкции тяжелой части органической массы нефти, являются межэлектродное расстояние, продолжительность обработки и разрядное напряжение.
\end{abstract}

Ключевые слова: электрогидроимпульсная технология, нефтяной шлам, кинематическая вязкость, межэлектродное расстояние, напряжение.

\section{References}

1 Bocharov, V.S., Nadirov, N.K., \& Krivtsov, I.P. et al. (1987). Neftebituminoznie porody [Oil-bituminous rocks]. Tekhnika $i$ tekhnolohiia dobychi i transportirovaniia - Technique and technology of extraction and transportation, Alma-Ata [in Russian].

2 Mazlova, Ye.A., \& Menshikova, I.A. (2010). Shlamovye otkhody neftegazovykh kompanii [Sludge waste of oil and gas companies]. Zashchita okruzhaiuchei sredy v neftegazovom komplekse - Protecting the environment in the oil and gas complex, 1, 21-22 [in Russian].

3 Krupets, V.I., Usov, A.F., \& Tsukerman, V.A. (2002). Elektrohidroimpulsnaia dezintehratsiia materialov [Electrohydropulse disintegration of materials]. Moscow: Nauka [in Russian].

4 Samarina, O.A. (2011). Sovershenstvovanie tekhnolohii obrabotki visokokontsentrirovannykh stochnykh vod nakopitelei neftekhimicheskikh predpriiatii [Perfection of technology of processing of highly concentrated wastewater of storage tanks of petrochemical enterprises]. Extendet abstract of candidate's thesis. Penza [in Russian].

5 Tsin Golin, Luan Minmin, \& Chen Tintin. (2011). Perspektivy razvitiia protsessov pererabotki nefteshlamov [Prospects for the development of oil sludge processing]. Khimiia i tekhnolohiia topliv $i$ masel - Chemistry and technology of fuels and oils, 4, 4454 [in Russian].

6 Ferdman, V.M. (2012). Kompleksnaia tekhnolohia utilizatsii nefteshlamov i likvidatsiia nefteshlamovykh ambarov v promyslovykh usloviiakh [Integrated technology of oil sludge utilization and liquidation of oil sludge barns in fishing conditions]. Extendet abstract of candidate's thesis. Ufa [in Russian].

7 Nadirov, N.K. (2001). Visokoviazkie nefti i prirodnye bitumy. Dobicha. Podgotovka. Transportirovka. [High viscosity oil and natural bitumen. Extraction. Preparation. Transportation]. (Vol. 2). Almaty: Gylym. 